\title{
Expression of a novel reticulon-like gene in human testis
}

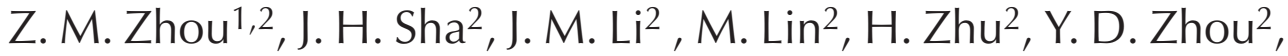 \\ L. R. Wang ${ }^{2}$, H. Zhu ${ }^{2}$, Y. Q. Wang ${ }^{1}$ and K. Y. Zhou ${ }^{1}$ \\ ${ }^{1}$ Institute of Genetic Resources, Nanjing Normal University, Nanjing, Jiangsu Province \\ 210029, People's Republic of China; and ${ }^{2}$ Key Laboratory of Reproductive Medicine, \\ Nanjing Medical University, Nanjing, Jiangsu Province, 210029, People's Republic of China
}

Identification of genes that are specifically expressed in the adult testis or the fetal testis is important for the study of genes related to the development of the testis. In this study, a human testis cDNA microarray was established. PCR products of 9216 clones from a human testis cDNA library were dotted on a nylon membrane; mRNA from adult and fetal testes were purified and probes were prepared by a reverse transcription reaction with testis mRNA as template. The microarray was hybridized with probes of adult and fetal testes, and 96.8 and $95.4 \%$ of clones were positive, respectively. In total, 731 clones were differentially expressed: $\mathbf{5 9 2}$ were highly expressed in adult testis and $\mathbf{1 3 9}$ were highly expressed in fetal testis. Among these genes, a new reticulon (Rtn)-like gene was detected and named Rtn-T. Rtn-T was highly expressed in adult human testis. The cDNA of Rtn-T contains 3491 bp and the putative protein had 968 amino acids. This protein is homologous to the six known members of the Rtn family (KIAA0886, Rtn xL, reticulon 4a, Nogo-A, Nogo-A short form, and brain my043) but was different at the $5^{\prime}$ end. All homologues originate from one gene, and result from both different promotor regions and different splicing. Rtn-T lacks the first exon and contains a second exon that is lacking in the other homologues. Rtn-T is shorter than KIAA0886, Rtn $x L$, reticulon $4 \mathrm{a}$ and Nogo-A, but longer than the Nogo-A short form and brain my043. Sequence analysis showed that Rtn-T protein has two hydrophobic regions that may be membranespanning domains. Expression profiles showed that Rtn-T is specifically and strongly expressed in testis. The results of the present study indicate that the Rtn-T gene is differentially expressed in adult and fetal testes and encodes a membrane protein that may have a function in testis development.

\section{Introduction}

The testis performs two fundamental functions: androgen secretion and spermatogenesis. Spermatogenesis is a complex and efficient process that begins with the division and differentiation of the spermatogenic stem cell within the seminiferous tubule of the testis. Because meiosis is different from mitosis, expression of genes in the testis is different from that in other organs. In addition, as spermatogenesis begins at puberty, the expression of genes differs at different stages, for example in adult and fetal testis (Eddy, 1998; Hecht, 1998; Sutton, 2000). Study of genes specifically expressed in the testis at different stages of development may reveal new genes related to testis function, particularly spermatogenesis (McCarrey, 1998). In the present study, human testis cDNA microarrays were used to identify the genes specifically expressed in adult or fetal testes and a new reticulon-like gene was found. Reticulon (Rtn) is a gene family and all Rtn proteins possess a 200 amino acid residue region of sequence similarity at the C terminus (Van de Velde et al., 1994; Roebroek et al., 1996, 1998; Moreira et al., 1999; Morris et al., 1999).

Email:Zhouzm@njmu.edu.cn
Related sequences have been recognized in human, bovine, mouse, rat, fly and worm genomes (Spillmann et al., 1998; Moreira et al., 1999; Schafer et al., 2001). Several homologous genes have been reported, including Nogo-A, Nogo-B, Nogo-C, Rtn 1, Rtn 2, Rtn 3 and Rtn 4 (Hens et al., 1998; GrandPre et al., 2000). Rtn proteins are expressed in neuroendocrine cells, lung carcinoma cells, oligodendrocytes and adipocytes (Senden et al., 1997; Morris et al., 1999; Chen et al., 2000; Prinjha et al., 2000) but their function is unclear, although it might be related to axon extension and apoptosis. There have been no reports to the authors' knowledge of studies investigating the relationship between Rtn and testis function.

\section{Materials and Methods}

\section{Construction of human testis CDNA microarrays}

The Human Testis 5'-STRETCH PLUS cDNA library was ordered from Clontech, Palo Alto, CA (catalogue number HL5503U, source of insert cDNA was 25 caucasians aged $20-65$ years, average length of insert cDNA $=3.4 \mathrm{~kb}$ ). Each $\lambda$ TriplEx2 clone was converted to a $\mathrm{p} \lambda$ TriplEx2 clone and excised with Eschericia coli BM25.8, and the complete plasmid was circularized from the recombinant phage according to the Clontech Manual PT3003-1. 
The plasmids were extracted by alkaline lysis using the modified method of Sambrook et al. (1989) and the samples were stored in 96 -well trays at $-70^{\circ} \mathrm{C}$.

The gene sequence was amplified from the plasmid clone by PCR to produce DNA for spotting the microarray. Primers were designed depending on the $5^{\prime}$ and $3^{\prime}$ sequences of $\lambda$ TriplEx2 vector flanking the insert. The $5^{\prime}$ primer was CCATTGTGTTGGTACCCGGGAATTCG, interval $6 \mathrm{bp}$ to insert CDNA site, and the $3^{\prime}$ primer was ATAAGCTTGCTCGAGTCTAGAGTCGAC, interval 7 bp to insert cDNA site. In total, 9216 clones selected randomly from the cDNA library were amplified. The PCR products contained $2.0-7.0 \mathrm{~kb}$. They were stored at $-20^{\circ} \mathrm{C}$.

A cDNA array was assembled with 9216 samples of PCR product. Each sample was dotted on an $8 \mathrm{~cm} \times 12 \mathrm{~cm}$ nylon membrane (Amersham Pharmacia Biotech, Bucks, lot number YA1103) using an automatic arrayer (BioRobotics, Cambridge). Two dots for each sample were applied: a total of 18432 dots representing 9216 samples. DNA was crosslinked to the nylon membrane by UV light. Eight housekeeping genes were used as positive controls: ribosomal protein S9 (RPS9), actin gamma, glyceraldehyde-3-phosphate dehydrogenase (GAPD), hypoxanthine phosphoribosyltransferase 1(HPRT1), Homo sapiens mRNA for a $23 \mathrm{kDa}$ highly basic protein, ubiquitin $\mathrm{C}$ (UBC), phospholipase $\mathrm{A} 2$ and ubiquitin carboxyl-terminal esterase L1 (UCHL1). $\lambda$ TriplEx2 phage DNA and PUC18 plasmid DNA were used as negative controls. Twelve spots were distributed in each membrane for each control cDNA.

\section{Screening of differentially expressed genes in adult or fetal testis}

Testes from deceased human adults $(n=2)$ and spontaneously aborted 6-month-old fetuses $(n=3)$ were collected. Adult and fetal testes were homogenized separately. Total mRNA was extracted according to the Trizol RNA isolation protocol (Gibco BRL, Grand Island, NY) and quantified with a UV spectrometer after electrophoresis. The Poly $(\mathrm{A})+$ mRNA was purified using an affinity column filled with poly(dT) resins (Qiagen, Hilden). The probes were prepared by incorporation of [ $\left.{ }^{33} \mathrm{P}\right] \mathrm{dATP}$ in a reverse transcription reaction using $2 \mu \mathrm{g}$ purified mRNA as the template, and an oligo(dT) as the primer with Moloney murine leukaemia virus (M-MLV) reverse transcriptase. Each labelling reaction was carried out with $200 \mu \mathrm{Ci}\left[\alpha^{33} \mathrm{P}\right] d \mathrm{ATP}$ according to the manufacturer's instructions (NEN Life Science, Boston, MA).

Nylon membranes spotted with cDNA fragments were prehybridized with $20 \mathrm{ml}$ prehybridization solution $(6 \times$ sodium chloride-sodium citrate buffer (SSC), 0.5\% SDS, $5 \times$ Denhardt compound, $100 \mu$ g denatured salmon sperm DNA ml-1) at $68^{\circ} \mathrm{C}$ for $3 \mathrm{~h}$. Overnight hybridization with the ${ }^{33}$ P-labelled cDNA from testis samples was carried out in $6 \mathrm{ml}$ hybridization solution $(6 \times$ SSC, $0.5 \%$ SDS, $100 \mu \mathrm{g}$ denatured salmon sperm DNA $\mathrm{ml}^{-1}$ ), and followed by stringent washing with $20 \mathrm{ml}$ wash solution $(10 \%$ SSC,
$0.5 \%$ SDS) at $65^{\circ} \mathrm{C}$ for $1 \mathrm{~h}$. Membranes were exposed to phosphor screen overnight and scanned using a FLA-3000A fluorescent image analyser (Fuji Photo Film, Tokyo). The radioactive intensity of each spot was linearly scanned with a 65536 gray-grade and a pixel size of $50 \mu \mathrm{m}$, and interpreted using the array gauge software (Fuji Photo Film). After subtraction of the background from an area where no PCR product was spotted, clones with an intensity density $>10$ were considered as positive signals. Hybridization data would be considered invalid if there was a difference of $>1.5$-fold in the intensity of any of the 12 control spots for the same control cDNA between arrays. The hybridization intensity of corresponding dots in adult and fetus were compared. If the difference in values of spot intensity in adult and fetus was more than threefold higher or lower, the corresponding genes were considered as differentially expressed.

\section{Sequence identification and analysis}

cDNA clones for predicted genes were proliferated. The amplified cDNA plasmids were isolated and purified in mini-preps (QIAprep Spin Miniprep Kit, Qiagen) and the inserts were sequenced using an ABI 377 automatic sequencing machine. For all clones, GenBank databases were searched for sequence homologies. The nucleic and deduced amino acid sequences were analysed using Gene Runner software.

\section{Expression profiles of Rtn-T}

After sequence identification and analysis, a reticulon (Rtn)-like gene, named Rtn-T, was identified. The expression profile of Rtn-T was determined using PCR screening. Multiple tissue cDNA panels including brain, heart, kidney, liver, lung, pancreas, placenta and skeletal muscle were purchased from Clontech (number 1420-1). Testis cDNA was amplified from normal human adult testis using RT-PCR. The Rtn-T specific primers were as follows: upstream 5' ACATTGACCCAACCGCAGT 3' (nt 40-58), and downstream 5' TTTCACGATTATTTCTTCCCTA 3' (nt 517-538). The upstream primer was located in the specific region of the Rtn-T. The downstream primer is homologous with other genes of the Rtn family. The PCR product was $498 \mathrm{bp}$ in size. G3PDH was used as positive control. The reagents in $30 \mu \mathrm{l} P C R$ reaction tubes were as follows: $10 \times 3 \mu \mathrm{l}$ PCR buffer, $2.4 \mu \mathrm{l}$ of $25 \mathrm{mmol} \mathrm{Mg}^{2+} \mathrm{I}^{-1}, 2.4 \mu \mathrm{l}$ of $2 \mathrm{mmol}$ dNTP $\mathrm{I}^{-1}, 0.2 \mu \mathrm{l}$ of 5 iu tag DNA polymerase $\mu \mathrm{l}^{-1}$, 5 pmol upstream primer, 5 pmol downstream primer, $3 \mu \mathrm{l}$ cDNA sample $(0.6 \mathrm{ng})$. PCR conditions were as follows: denaturation at $94^{\circ} \mathrm{C}$ for $30 \mathrm{~s}$, annealing at $58^{\circ} \mathrm{C}$ for $30 \mathrm{~s}$ and extension at $72^{\circ} \mathrm{C}$ for $1 \mathrm{~min}$. The first cycle had a denaturation period of $5 \mathrm{~min}$. The last cycle had an extension period of $7 \mathrm{~min}$. Thirty cycles of PCR were performed and the PCR products were analysed after electrophoresis. 


\section{Results}

\section{Differential expression of genes in adult and fetal testes}

The microarrays of the human testis cDNA were hybridized with cDNA probes prepared from the mRNA of adult and fetal testes. Signals were obtained from 8925 spots (about $96.8 \%$ of the cDNA clones) in the case of adult testis, and 8795 spots (about $95.4 \%$ of the cDNA clones) in fetal testis. Most genes were expressed in both adult and fetal testes and the remainder were expressed only in adult or fetal testis. Among the cDNA clones that gave signals, 731 were differentially expressed in adult or fetal testis: 592 clones were highly expressed in adult testis, whereas 139 were expressed in fetal testis. The difference in intensity in these cases was at least threefold. The reciprocal expression characteristics of these genes indicate that different sets of genes are involved in different developmental stages.

\section{Sequence identification and the foundation of Rtn-T gene}

Sequence identification of all the above differentially expressed genes showed that 37 were novel genes that have not been reported and 90 have at least one homologous gene reported before. One of these novel genes was a reticulon-like gene. The hybridization intensities of this Rtnlike gene in adult and fetal testes were 180.64 and 50.15, respectively (Fig. 1). This gene was expressed in both adult and fetal testis, but the expression in adult testis was approximately 3.60 -fold higher than that in fetal testis. The full length cDNA was 3491 bp and contained an open reading frame (nt 179-3139) that encodes a $108 \mathrm{kDa}$ protein of 986 amino acids (Fig. 2). The methionine at nt 179-181 was almost certainly the site of initiation because there was an up-frame upstream stop code at nt 44-46. Blast search in the human genome database showed that this Rtn-like gene consisted of nine exons. Blast search of the contig map showed that all exons were located within chromosome $2 \mathrm{p} 16$, so this Rtn-like gene was mapped to chromosome $2 \mathrm{p} 16$. Analysis of the amino acid sequence revealed one signal sequence of 26 amino acids at the $\mathrm{N}$-terminal and two long hydrophobic stretches of 37 and 35 amino acids at the C-terminal. These stretches may be transmembrane segments, although they are much longer than the typical transmembrane segments of approximately 20 amino acids. There were no other functional domains as determined by comparative sequence analysis. This Rtn-like gene has GenBank accession number AF333336.

\section{Expression profiles of predicted genes}

PCR and electrophoresis showed that the novel Rtn-like gene was particularly and strongly expressed in human testis (Fig. 3) and therefore was named Rtn-T. Rtn-T was not expressed in brain, heart, kidney, liver, lung, pancreas, placenta, or skeletal muscle.
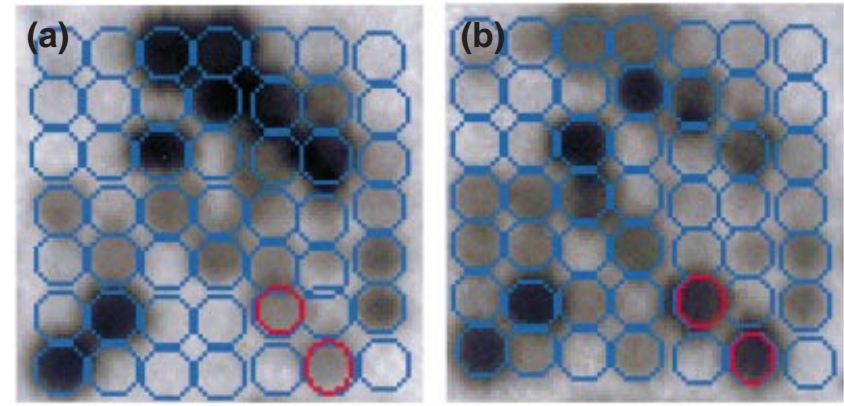

Fig. 1. Partial cDNA hybridization images showing differential expression of Rtn-T in (a) 6-month-old fetal and (b) adult human testes (red circles). The hybridization intensity in fetal and adult testes was 50.15 and 180.64 , respectively.

Homologous analysis between Rtn-T and other members of the Rtn family

Blast searches revealed that Rtn-T was highly homologous to six other genes, all of which belong to the Rtn family and have been identified in humans: KIAA0886 (AB020693), Rtn-xL (AB040462), reticulon 4a (AF148537), Nogo-A (AJ251383), Nogo-A short form (AF320999) and brain my043 (AF063601) (Fig. 4). The cDNA of Rtn-T is shorter than that of KIAA0886, Rtn-xL, reticulon 4a and Nogo-A. The first exon of Rtn-T at the 5' end was different from that of the above four genes. However, Rtn-T had a shorter ORF and coded a small protein (986 amino acids), which had a similar $\mathrm{C}$ terminus to all Rtn proteins. The cDNA of Rtn-T was longer than those of Nogo-A short form and brain my043. The $\mathrm{C}$ terminus of Rtn- $\mathrm{T}$ was also similar to that of Nogo A short form and brain my043 (Fig. 5).

\section{Discussion}

In the present study, cDNA microarray was used to identify the genes related to the development of human testis and a reticulon-like gene, named Rtn-T, was identified. The results indicated that the use of high-density arrays of spotted human testis cDNA clones offers a number of advantages in the identification of genes specifically expressed in adult or fetal testis. The results also showed that Rtn-T is differentially expressed in adult testis and encodes a membrane protein that may have a function in the development of human testis.

Different approaches have been developed to gain information on the amount of gene expression on the basis of intensity measurement related to differential expression, for example, whole-mount in situ hybridization (Wilkinson and Nieto, 1993), differential display technology (Liang and Pardee, 1992) and cDNA microarray (Eickhoff et al., 2000). Some of these methods have been used in the identification of genes expressed in the testis. Goto et al. (2001) identified a testis-specific member of the olfactory receptor gene family in human primordial germ cells with differential 


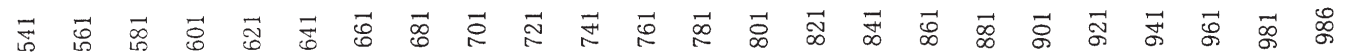

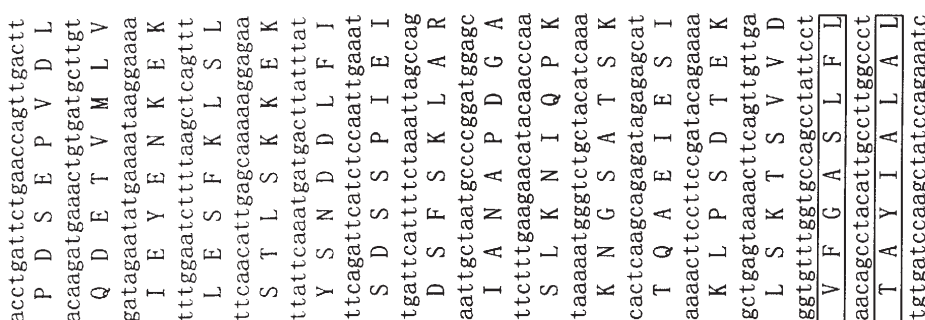

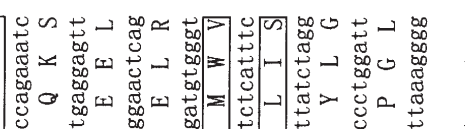

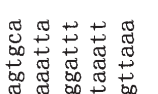

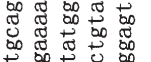

0
$+\infty$
$+\infty$
0
0
0

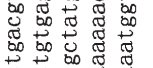

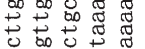

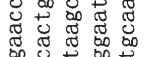

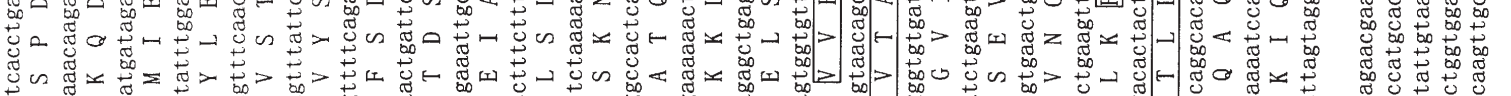

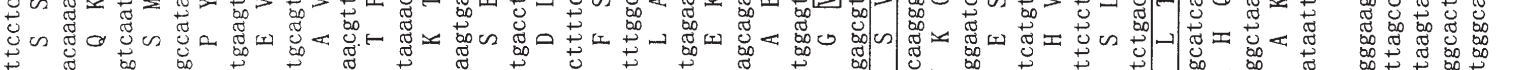

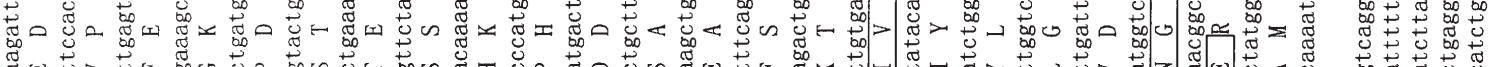

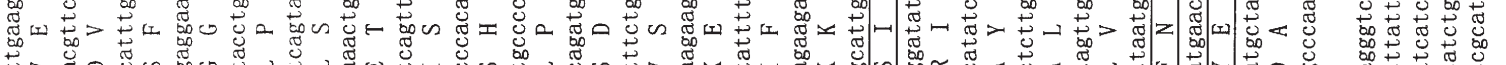

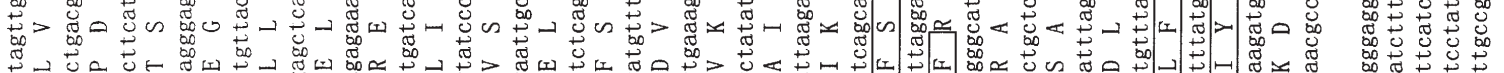

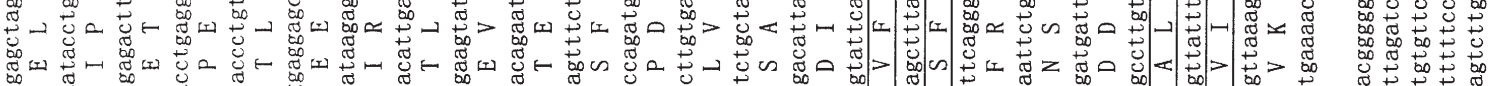

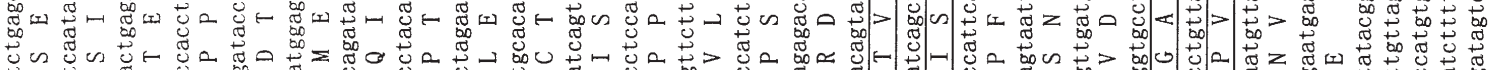

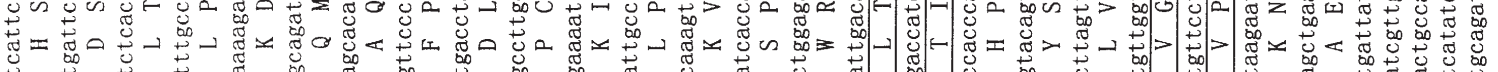

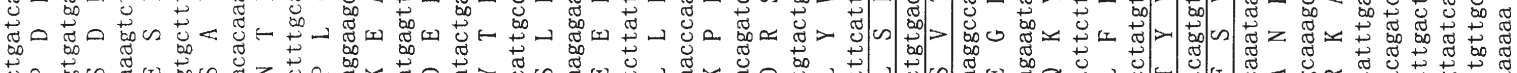

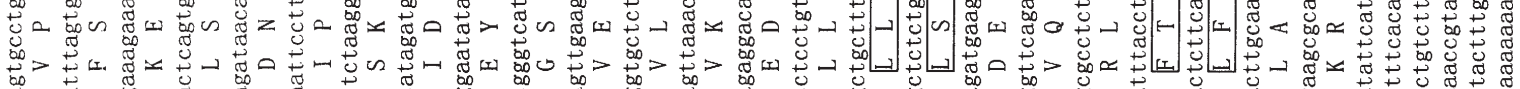

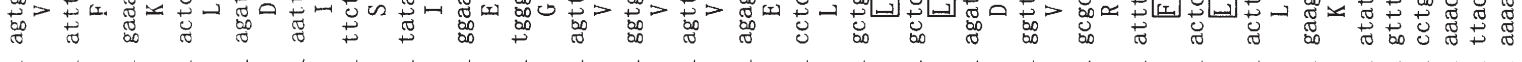

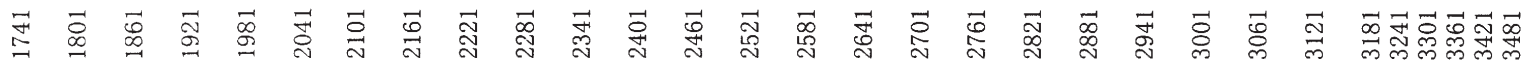

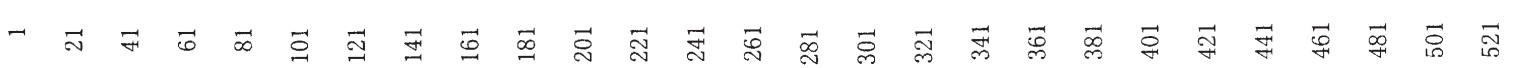

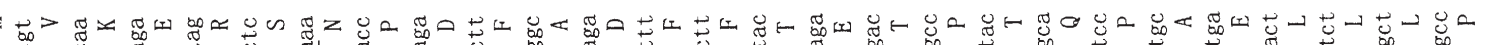

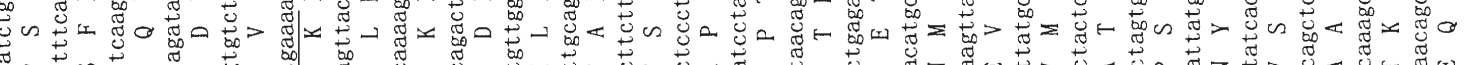

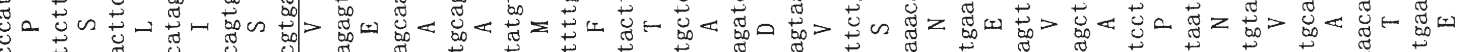

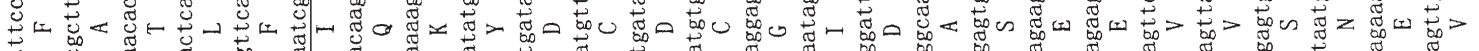

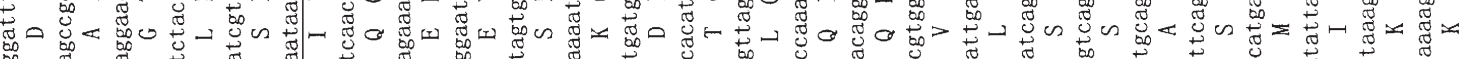

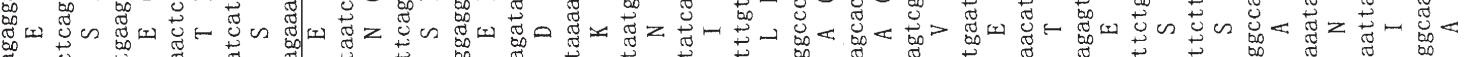

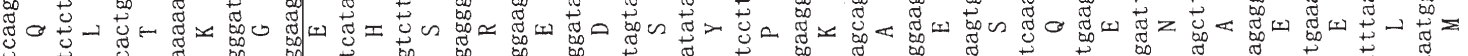

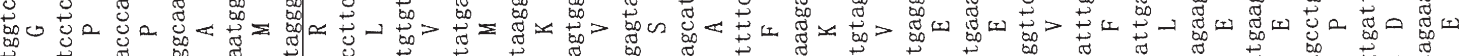

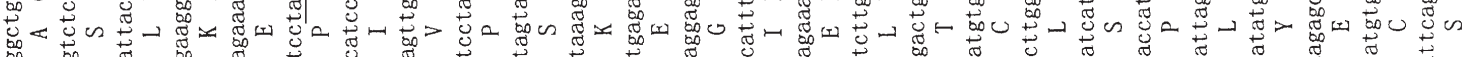

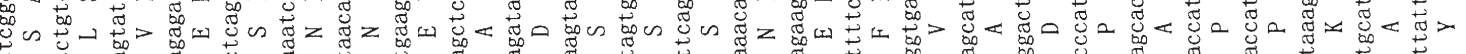

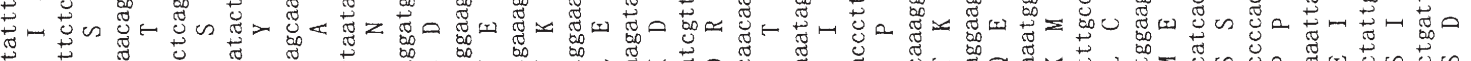

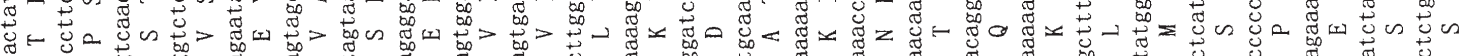

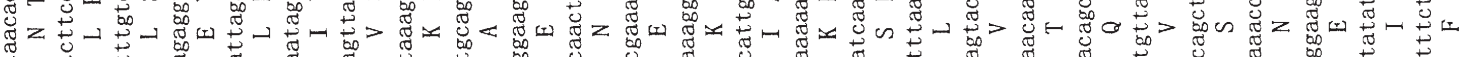

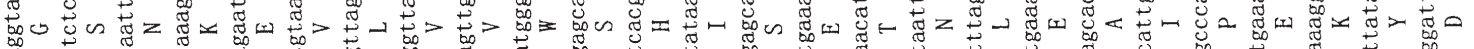

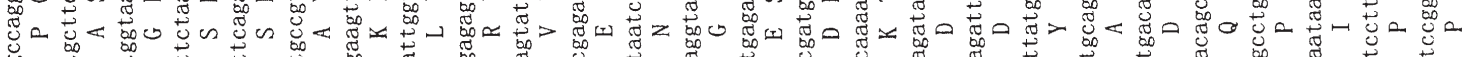

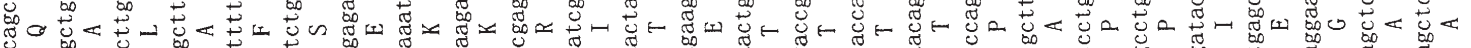

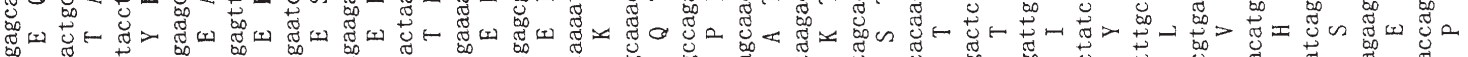

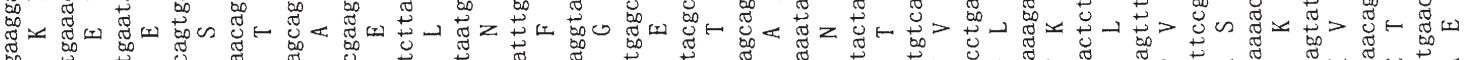

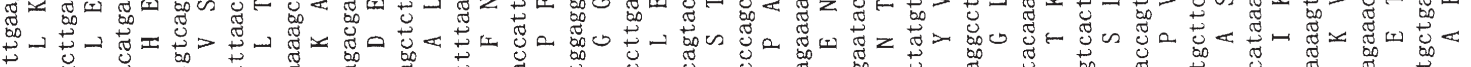

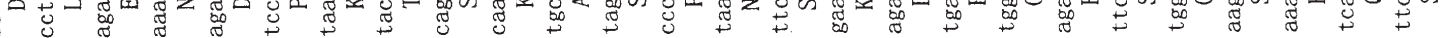

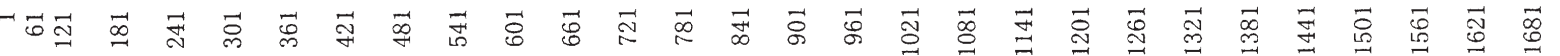

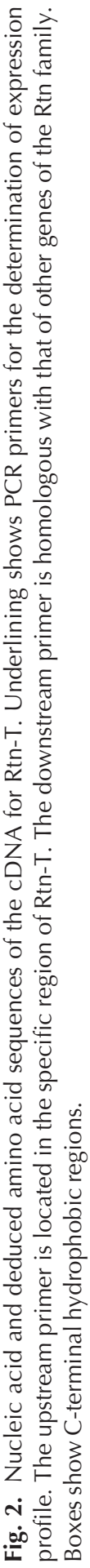



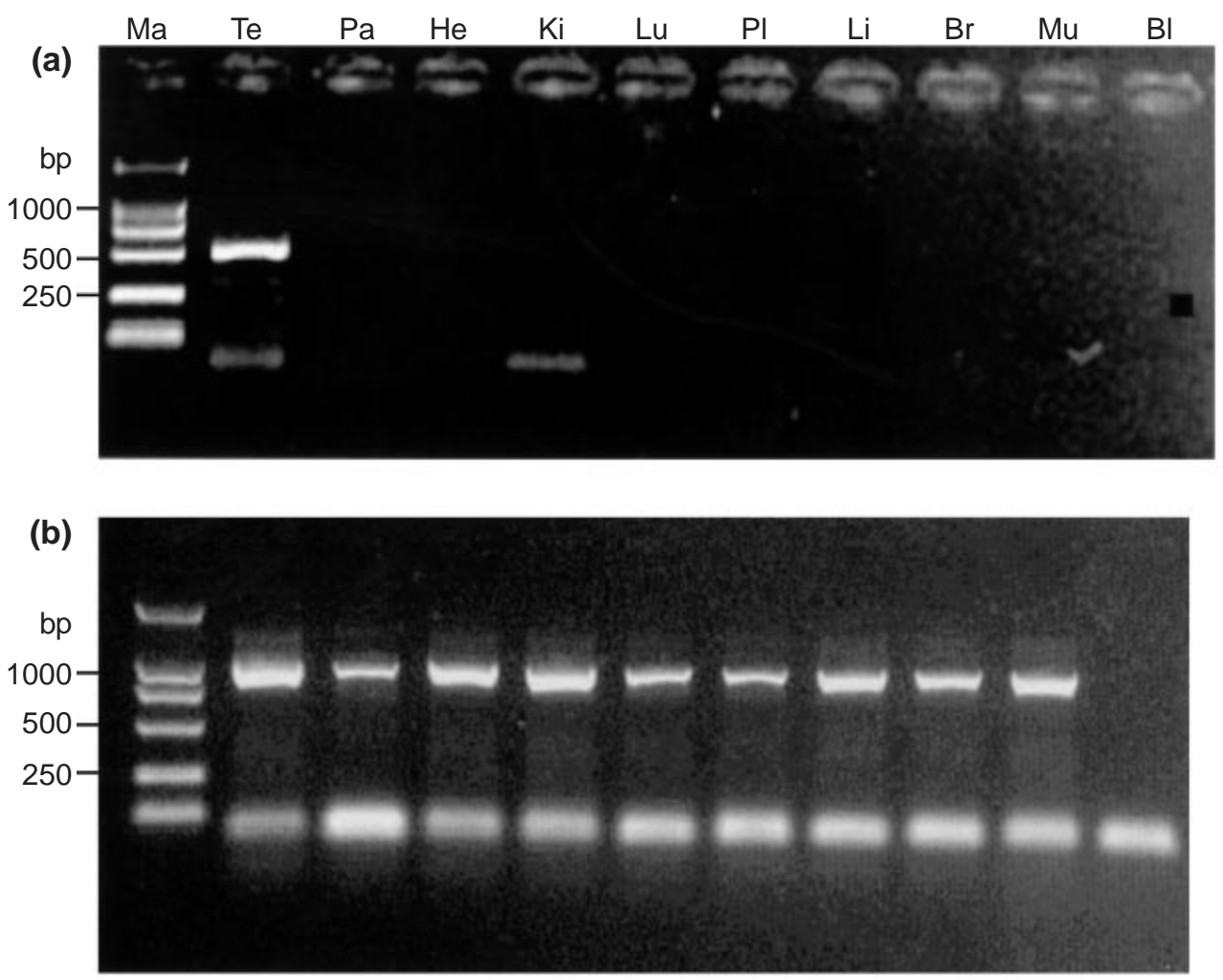

Fig. 3. Expression profiles of (a) amplified Rtn-T and (b) amplfied G3PDH as control after electrophoresis. PCR product of Rtn-T was $498 \mathrm{bp}$. Rtn-T was specifically and strongly expressed in testis and there was no expression in any other organs. G3PDH was expressed in all organs. Ma, marker; Te, testis; Pa, pancreas; He, heart; Ki, kidney; Lu, lung; Pl, placenta; Li, liver; Br, brain; Mu, muscle; $\mathrm{Bl}$, blank.

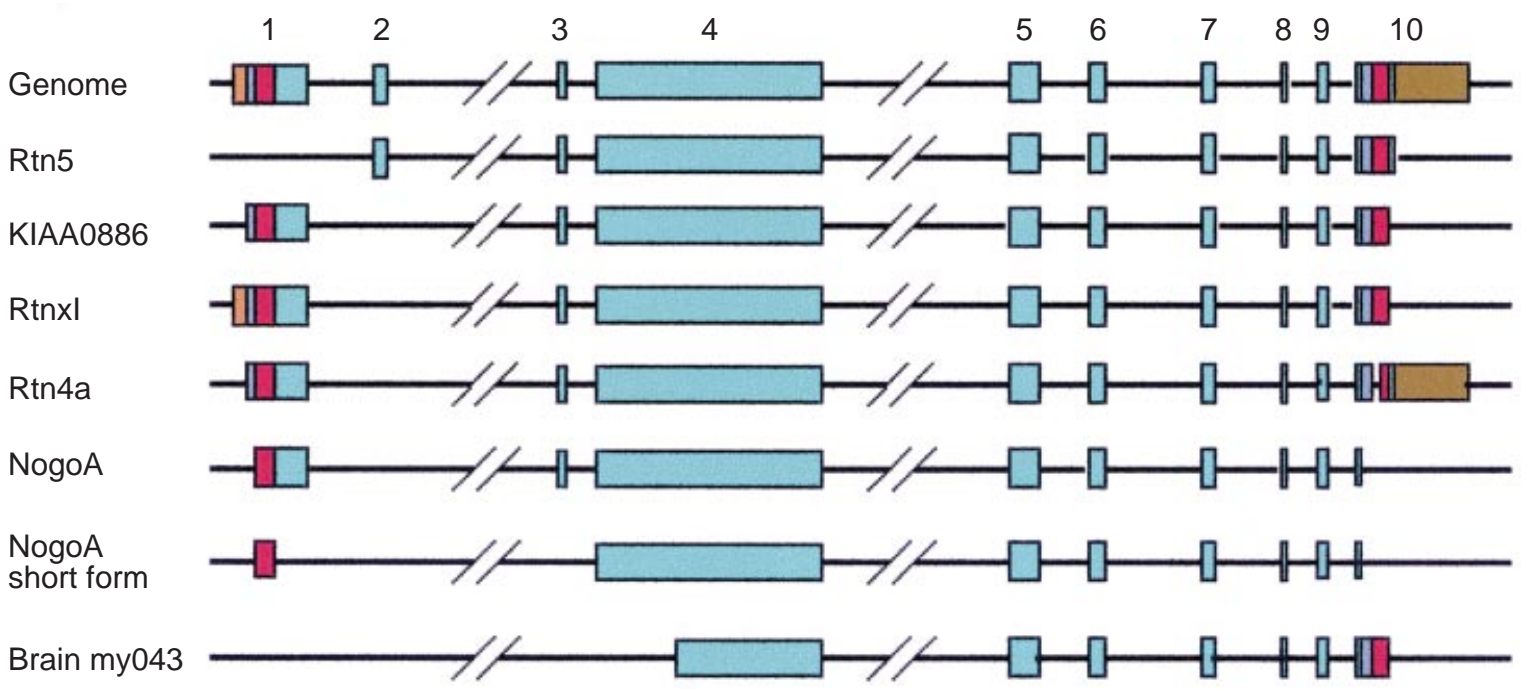

Fig. 4. Transcript and splicing comparison of Rtn-T with homologous genes. Seven homologues originate from one gene and consist of 10 exons (shown as boxes). Exon 2 is present only in Rtn-T and Rtn-T lacks exon 1. Nogo-A short form lacks exon 2, and brain my043 lacks exons 1 and 2. The length of exons 1 and 10 varies among the homologues (differences expressed by different colours). 
A
1

MEDLDQSPLVSSSDSPPRPQPAFKYQFVREPEDEEEEEEEEEEDEDEDLEELEVLERKPAAGLSAAPVPTAPAAGAPLMDFGNDFVPPAP MEDLDQSPLVSSSDSPPRPQPAFKYQFVREPEDEEEEEEEEEEDEDEDLEELEVLER-

91

RGPLPAAPPVAPERQPSWDPSPVSSTVPAPSPLSAAAVSPSKLPEDDEPPARPPPPPPASVSPQAEPVWTPPAPAPAAPPSTPAAPKRRG MDLKEQPGNTISAGQEDFPSVLLETAASLPSLSPLSAASFKEHEYLGNLSTVLPTEGTLQENVS 270 SSGSVDETLFALPAASEPVIRSSAENMDLKEQPGNTISAGQEDFPSVLLETAASLPSLSPLSAASFKEHEYLGNLSTVLPTEGTLQENVS

271 EASKEVSEKAKTLLIDRDLTEFSELEYSEMGSSFSVSPKAESAVIVANPREEI IVKNKDEEEKLVSNNILHNQQELPTALTKLVKEDEVV 360 EASKEVSEKAKTLLIDRDLTEFSELEYSEMGSSFSVSPKAESAVIVANPREEIIVKNKDEEEKLVSNNILHNQQELPTALTKLVKEDEVV -TEFSELEYSEMGSSFSVSPKAESAVIVANPREEI IVKNKDEEEKLVSNNILHNQQELPTALTKLVKEDEVV

361 SSEKAKDSFNEKRVAVEAPMREEYADFKPFERVWEVKDSKEDSDMLAAGGKIESNLESKVDKKCFADSLEQTNHEKDSESSNDDTSFPST 450 SSEKAKDSFNEKRVAVEAPMREEYADFKPFERVWEVKDSKEDSDMLAAGGKIESNLESKVDKKCFADSLEQTNHEKDSESSNDDTSFPST SSEKAKDSFNEKRVAVEAPMREEYADFKPFERVWEVKDSKEDSDMLAAGGKIESNLESKVDKKCFADSLEQTNHEKDSESSNDDTSFPST

451 PEGIKDRSGAYITCAPFNPAATESIATNIFPLLGDPTSENKTDEKKIEEKKAQIVTEKNTSTKTSNPFLVAAQDSETDYVTTDNLTKVTE 540 PEGIKDRSGAYITCAPFNPAATESIATNIFPLLGDPTSENKTDEKKIEEKKAQIVTEKNTSTKTSNPFLVAAQDSETDYVTTDNLTKVTE PEGIKDRSGAYITCAPFNPAATESIATNIFPLLGDPTSENKTDEKKIEEKKAQIVTEKNTSTKTSNPFLVAAQDSETDYVTTDNLTKVTE

541 EVVANMPEGLTPDLVQEACESELSEVTGTKIAYETKMDLVQTSEVMQESLYPAAQLCPSFEESEATPSPVLPDIVMEAPLNSAVPSAGAS 630 EVVANMPEGLTPDLVQEACESELNEVTGTKIAYETKMDLVQTSEVMQESLYPAAQLCPSFEESEATPSPVLPDIVMEAPLNSAVPSAGAS EVVANMPEGLTPDLVQEACESELNEVTGTKIAYETKMDLVQTSEVMQESLYPAAQLCPSFEESEATPSPVLPDIVMEAPLNSAVPSAGAS ----MPEGLTPDLVQEACESELNEVTGTKIAYETKMDLVQTSEVMQESLYPAAQLCPSFEESEATPSPVLPDIVMEAPLNSAVPSAGAS

631 VIQPSSSPLEASSVNYESIKHEPENPPPYEEAMSVSLKKVSGIKEEIKEPENINAALQETEAPYISIACDLIKETKLSAEPAPDFSDYSE 720 VIQPSSSPLEASSVNYESIKHEPENPPPYEEAMSVSLKKVSGIKEEIKEPENINAALQETEAPYISIACDLIKETKLSAEPAPDFSDYSE VIQPSSSPLEASSVNYESIKHEPENPPPYEEAMSVSLKKVSGIKEEIKEPENINAALQETEAPYISIACDLIKETKLSAEPAPDFSDYSE VIQPSSSPLEASSVNYESIKHEPENPPPYEEAMSVSLKKVSG IKEEIKEPENIMQLFKKQKLLIYLLHVDLIKETKLSAEPAPDFSDYSE

721 MAKVEQPVPDHSELVEDSSPDSEPVDLFSDDSIPDVPQKQDETVMLVKESLTETSFESMIEYENKEKLSALPPEGGKPYLESFKLSLDNT 810 MAKVEQPVPDHSELVEDSSPDSEPVDLFSDDSIPDVPQKQDETVMLVKESLTETSFESMIEYENKEKLSALPPEGGKPYLESFKLSLDNT MAKVEQPVPDHSELVEDSSPDSEPVDLFSDDSIPDVPQKQDETVMLVKESLTETSFESMIEYENKEKLSALPPEGGKPYLESFKLSLDNT MAKVEQPVPDHSELVEDSSPDSEPVDLFSDDSIPDVPQKQDETVMLVKESLTETSFESMIEYENKEKLSALPPEGGKPYLESFKLSLDNT

811 KDTLLPDEVSTLSKKEKIPLQMEELSTAVYSNDDLFISKEAQIRETETFSDSSPIEIIDEFPTLISSKTDSFSKLAREYTDLEVSHKSEI 900 KDTLLPDEVSTLSKKEKIPLQMEELSTAVYSNDDLFISKEAQIRETETFSDSSPIEI IDEFPTLISSKTDSFSKLAREYTDLEVSHKSEI KDTLLPDEVSTLSKKEKIPLQMEELSTAVYSNDDLFISKEAQIRETETFSDSSPIEI IDEFPTLISSKTDSFSKLAREYTDLEVSHKSEI KDTLLPDEVSTLSKKEKIPLQMEELSTAVYSNDDLFISKEAQIRETETFSDSSPIEI IDEFPTLISSKTDSFSKLAREYTDLEVSHKSEI

910 ANAPDGAGSLPCTELPHDLSLKNIQPKVEEKISFSDDFSKNGSATSKVLLLPPDVSALATQAEIESIVKPKVLVKEAEKKLPSDTEKEDR 990 ANAPDGAGSLPCTELPHDLSLKNIQPKVEEKISFSDDFSKNGSATSKVLLLPPDVSALATQAEIESIVKPKVLVKEAEKKLPSDTEKEDR ANAPDGAGSLPCTELPHDLSLKNIQPKVEEKISFSDDFSKNGSATSKVLLLPPDVSALATQAEIESIVKPKVLVKEAEKKLPSDTEKEDR ANAPDGAGSLPCTELPHDLSLKNIQPKVEEKISFSDDFSKNGSATSKVLLLPPDVSALATQAEIESIVKPKVLVKEAEKKLPSDTEKEDR

991 SPSAIFSAELSKTSVVDLLYWRDIKKTGVVFGASLFLLLSLTVFSIVSVTAYIALALLSVTISFRIYKGVIQAIQKSDEGHPFRAYLESE 1080 SPSAIFSAELSKTSVVDLLYWRDIKKTGVVFGASLFLLLSLTVFSIVSVTAYIALALLSVTISFRIYKGVIQAIQKSDEGHPFRAYLESE SPSAIFSAELSKTSVVDLLYWRDIKKTGVVFGASLFLLLSLTVFSIVSVTAYIALALLSVTISFRIYKGVIQAIQKSDEGHPFRAYLESE SPSAIFSAELSKTSVVDLLYWRDIKKTGVVFGASLFLLLSLTVFSIVSVTAYIALALLSVTISFRIYKGVIQAIQKSDEGHPFRAYLESE

1081 VAISEELVQKYSNSALGHVNCTIKELRRLFLVDDLVDSLKFAVLMWVFTYVGALFNGLTLLILALISLFSVPVIYERHQAQIDHYLGLAN 1170 VAISEELVQKYSNSALGHVNCTIKELRRLFLVDDLVDSLKFAVLMWVFTYVGALFNGLTLLILALISLFSVPVIYERHQAQIDHYLGLAN VAISEELVQKYSNSALGHVNCTIKELRRLFLVDDLVDSLKFAVLMWVFTYVGALFNGLTLLILALISLFSVPVIYERHQAQIDHYLGLAN VAISEELVQKYSNSALGHVNCTIKELRRLFLVDDLVDSLKFAVLMWVFTYVGALFNGLTLLILALISLFSVPVIYERHQAQIDHYLGLAN 1

171 KNVKDAMAKIQAKIPGLKRKAE 1193 KNVKDAMAKIQAKIPGLKRKAE KNVKDAMAKIQAKIPGLKRKAE KNVKDAMAKIQAKIPGLKRKAE

Fig. 5. Comparison of the deduced amino acid sequence of Rtn-T with homologues. Line A: Rtn-T; line B: KIAA0886, Rtn xL, reticulon 4a and Nogo-A; line C: Nogo-A short form; line D: brain my043. Grey highlighted areas indicate differences in amino acid sequence. 
display. Raabe et al. (2001) also identified an SNF2 factor involved in mammalian development and cellular proliferation using this approach. Interest in and use of DNA array technology has increased markedly over the past 5 years, and there has been a surge in demand for different types of array. Although manufacturers offer a number of pre-made arrays, these are generally of utilitarian design and often cannot accommodate the specific requirements of focused research, such as a specific set of genes from a particular tissue. For this reason, some specific arrays, such as live expression array, have been established for particular studies. Rockett et al. (2001) produced a mouse testis expression array assembling 950 genes and used it in the study of gene expression patterns in testis. In the present study, an expression microarray was produced with 9216 clones from the human testis cDNA library. This microarray was used to find genes related to development of the testis by comparing expression in adult and fetal testes. Some genes were expressed mainly in adult testis and some mainly in fetal testis. The reciprocal expression characteristics of these genes indicates that different sets of genes are involved in different developmental stages, for example, those expressed mainly in adult testis may be related to spermatogenesis or androgen secretion. Study of these differentially expressed genes may reveal new genes related to spermatogenesis.

Sequence identification of 731 genes revealed that 37 were novel genes, whereas 90 have had at least one homologue reported before. One of these novel genes, a member of the reticulon gene family (Van de Velde et al., 1994; Roebroek et al., 1996, 1998; Moreira et al., 1999; Morris et al., 1999; Yang et al., 2000), was named Rtn-T. All Rtn proteins are anchored to membranes of the endoplasmic reticulum and share a 200 amino acid residue region of sequence similarity (70\% identical across the Rtn family) at the carboxyl terminus of the protein (Van de Velde et al., 1994; Roebroek et al., 1996, 1998; Moreira et al., 1999; Morris et al., 1999). The reticulon family consists of two main groups: Nogo and Rtn (also known as neuroendocrine-specific protein, NSP). DNA sequence analysis and northern blotting indicates that Nogo has three different transcripts (A, B and C) and protein products: Nogo-A (1163 amino acids), Nogo-B (360 amino acids) and Nogo-C (199 amino acids) (Chen et al., 2000). Rtn also has four alternative transcripts, Rtn 1-4 (Hens et al., 1998; GrandPre et al., 2000). All transcripts are similar at the C-end, but different at the $\mathrm{N}$-end. Reticulon-related sequences have been recognized in human, bovine, mouse, rat, fly and worm genomes (Spillmann et al., 1998; Moreira et al., 1999; Schafer et al., 2001). Rtn proteins are expressed in neuroendocrine cells, lung carcinoma cells, oligodendrocytes and adipocytes (Senden et al., 1997; Morris et al., 1999; Chen et al., 2000; Prinjha et al., 2000). Blast searches revealed that Rtn-T was highly homologous to six genes: KIAA0886, Rtn-xL, reticulon 4a, Nogo-A, Nogo-A short form and brain my043, all of which belong to the Rtn family. Blast searches of these homologues in the human genome revealed that all of these transcripts originate from one gene, and result from the use of alternative promotors and alternative splicing. In total, this gene has ten exons. Exon 2 occurs only in Rtn-T, which lacks exon 1. Blast search of amino acid sequences showed that the novel RtnT protein shared high homology with the proteins of the Rtn family at the carboxyl terminus, but the $\mathrm{N}$-end of Rtn-T was shorter than that of KIAA0886, Rtn-xL, reticulon 4a and Nogo-A, and longer than that of Nogo-A short form and brain my043. The sequence upstream of the ORF in Rtn-T was also different from that of other genes. This same difference is found in other members of the Rtn family, such as KIAA0886, Rtn-xL, reticulon 4a and Nogo-A, and this may explain why the genes of this family are specifically expressed in different organs or tissues and appear to have different functions. For example, Rtn 1 is expressed exclusively in neuroendocrine cells (van de Velde et al., 1994) and lung carcinoma cells with neuroendocrine phenotype (Senden et al., 1997). Tissue specificity indicates that Rtn 1 is related to the function of neuroendocrine cells. Nogo was firstly purified from bovine brain (Spillmann et al., 1998) and encodes at least three major protein products (Nogo-A, -B, and -C) (Chen et al., 2000). Human Nogo-A was derived during the Kazusa DNA Research Institute effort to sequence random high molecular weight brainderived cDNAs (Nagase et al., 1998). Nogo-A is expressed by oligodendrocytes and contributes to the failure of axonal regeneration in the adult central nervous system (Grandpre et al., 2000). Rtn 1 and Rtn XS were identified by Tagami et al. (2000), who reported that they were localized predominantly on the endoplasmic reticulum and could bind to $\mathrm{Bcl}-\mathrm{XL}$ and $\mathrm{Bcl}-2$. Rtn can also modulate antiapoptotic activity (Tagami et al., 2000). Bcl-2 and Bcl-XL serve as critical inhibitors of apoptosis triggered by a broad range of stimuli. Rtn-xL can interact with both $\mathrm{Bcl}-\mathrm{XL}$ and $\mathrm{Bcl}-2$, increase the localization of $\mathrm{BCl}-\mathrm{XL}$ and $\mathrm{BCl}-2$ on the endoplasmic reticulum, and reduce the anti-apoptotic activity of $\mathrm{BCl}-\mathrm{XL}$ and $\mathrm{BCl}-2$. Rtn-T is expressed in fetal and adult testis, but highly in adult testis, indicating that Rtn-T may be related to testis development and, in particular, spermatogenesis. It needs to be determined whether Rtn-T affects the process of spermatogenesis by influencing apoptosis.

Z. M. Zhou was supported by China National 973 fund, number G1999055901.

\section{References}

Chen MS, Huber AB, van der Haar ME, Frank M, Schnell N, Spillmann AA and Christ F (2000) Nogo-A is a mylin-associated neurite outgrowth inhibitor and an antigen for monoclonal antibodylN-1 Nature 403 434-437

Eddy EM (1998) Regulation of gene expression during spermatogenesis Cell and Development Biology 9 451-457

Eickhoff H, Schuchhardt J, Ivanov I et al. (2000) Tissue gene expression analysis using arrayed normalized cDNA libraries Gene Research 10 1230-1240

Goto T, Salpekar A and Monk M (2001) Expression of a testis-specific 
member of the olfactory receptor gene family in human primordial germ cells Molecular Human Reproduction 7 553-558

GrandPre T, Nakamura F, Vartanian T and Strittmatter SM (2000) Identification of the Nago inhibitor of axon regeneration as a reticulon protein Nature $\mathbf{4 0 3}$ 439-444

Hecht NB (1998) Molecular mechanism of male germ cell differentiation Bioassays 22 555-561

Hens J, Nuydens R, Geerts H, Senden NH, Van de Ven WJ, Roebroek AJ, Van de Velde HJ, Ramaekers FC and Broers JL (1998) Neuronal differentiation is accompanied by NSP-C expression Cell and Tissue Research 292 229-237

Liang P and Pardee A (1992) Differential display of eukaryotic messenger RNA by means of the polymerase chain reaction Science 257 967-971

McCarrey JR (1998) Spermatogenesis as a model system for developmental analysis of regulatory mechanisms associated with tissue-specific gene expression Cell and Development Biology 9 459-466

Moreira EF, Jaworski CJ and Rodriguez LR (1999) Cloning of a novel member of the reticulon gene family (RTN3) gene structure and chromosomal localization to 11q13 Genomics 58 73-81

Morris NJ, Ross SA, Neveu JM, Lane WS and Lienhard GE (1999) Cloning and characterization of a $22 \mathrm{kDa}$ protein from rat adipocytes a new member of the reticulon family Biochimica et Biophysica Acta 1450 68-76

Nagase T, Ishikawa K, Suyama M, Kikuno R, Hirosawa M, Miyajima N, Tanaka A, Kotani H, Nomura N and Ohara O (1998) Prediction of the coding sequences of unidentified human genes XII. The complete sequences of 100 new cDNA clones from brain which code for large proteins in vitro. DNA Research 5 355-364

Prinjha R, Moore SE, Vinson M, Blake S, Morrow R, Christie G, Michalovich D, Simmons DL and Walsh FS (2000) Inhibitor of neurite outgrowth in humans Nature 403 383-385

Raabe EH, Abdurrahman L, Behbehani G and Arceci RJ (2001) An SNF2 factor involved in mammalian development and cellular proliferation Developmental Dynamics 221 92-105

Rockett JC, Christopher Luft J, Brian Garges J, Krawetz SA, Hughes MR, Hee Kirn K, Oudes AJ and Dix DJ (2001) Development of a 950-gene DNA array for examining gene expression patterns in mouse testis Genome Biology 2 Research 0014.1-0014.9

Roebroek AJ, Ayoubi TA, Van de Velde HJ, Schoenmakers EF, Pauli IG and Van de Ven WJ (1996) Genomic organization of the human NSP gene, prototype of a gene family encoding reticulons Genomics 32 191-199
Roebroek AJ, Contreras B, Pauli IG and Van de Ven WJ (1998) cDNA cloning, genomic organization, and expression of the human RTN2 gene, a member of a gene family encoding reticulons Genomics 51 98-106

Sambrook J, Fritsch EF and Maniatis T (1989) Molecular Cloning: A Laboratory Manual 2nd Edn. Cold Spring Harbor Laboratory Press, New York

Schafer GL, Crabbe JC and Wiren KM (2001) Ethanol-regulated gene expression of neuroendocrine specific protein in mice brain region and genotype specificity Brain Research 897 139-149

Senden N, Linnoila I, Timmer E, Van de Velde H, Roebroek A, Van de Ven W, Broers J and Ramaekers F (1997) Neuroendocrine-specific protein (NSP)-reticulons as independent markers for non-small cell lung cancer with neuroendocrine differentiation Histochemical Cell Biology 108 155-165

Spillmann AA, Bandtlon CE, Lottspeich F, Keller F and Schwab ME (1998) Identification and characterization of a bovin neurite growth inhibitor (bNI-220) Journal of Biological Chemistry 27319 283-19 293

Sutton KA (2000) Molecular mechanisms involved in the differentiation of spermatogenic stem cells Reviews of Reproduction 5 93-98

Tagami S, Eguchi Y, Kinoshita M, Takeda M and Tsujimoto Y (2000) A novel protein, RTN-XS, interacts with both Bcl-XL and Bcl-2 on endoplasmic reticulum and reduces their anti-apoptotic activity Oncogene 23 5736-5746

Van de Velde NJ, Roebroek AJ, Senden NH, Ramekers FC and Van de Ven WJ (1994) NSP-encoded reticulons, neuroendocrine proteins of a novel gene family associated with membranes of endoplasmic reticulum Journal of Cell Science 107 2403-2416

Wilkinson DG and Nieto MA (1993) Detection of messenger RNA by in situ hybridization to tissue sections and whole mounts Methods in Enzymology 225 361-373

Yang J, Yu L, Bi AD and Zhao SY (2000) Assignment of the human reticulon 4 gene (RTN4) to chromosome $2 \mathrm{p} 14->2 \mathrm{p} 13$ by radiation hybrid mapping Cytogenetics and Cell Genetics 88 101-102

Received 10 May 2001.

First decision 25 July 2001.

Final manuscript received 30 October 2001.

Accepted 31 October 2001. 